\title{
Intracranial hypotension causing pituitary enlargement
}

\author{
Daniela WC Chan, ${ }^{1}$ Angel IY Wu, ${ }^{2}$ Katie Wynne ${ }^{1,3,4}$
}

'Department of Diabetes \& Endocrinology, John Hunter Hospital, Newcastle, NSW, Australia

2Department of Radiology, John Hunter Hospital, Newcastle, NSW, Australia

${ }^{3}$ Hunter Medical Research Institute, Newcastle, NSW, Australia

${ }^{4}$ University of Newcastle, Newcastle, NSW, Australia

\section{Correspondence to}

Dr Katie Wynne,

Katie-Jane.Wynne@hnehealth. nsw.gov.au

Accepted 20 April 2017

\section{(a) CrossMark}

To cite: Chan DWC, Wu AIY, Wynne K. BMJ Case Rep Published Online First: [please include Day Month Year]. doi:10.1136/bcr-2017220057

\section{DESCRIPTION}

A woman aged 67 years was referred with pituitary enlargement identified on CT scan. Imaging was performed to investigate a progressive, incapacitating, 12-month history of nausea, vertigo, gait disturbance and recurrent falls. Her presentation included chronic occipitofrontal headaches, which had increased in severity and were exacerbated by upright posture. She had a history of lumboperitoneal (LP) shunting for idiopathic intracranial hypertension, systemic hypertension, ischaemic heart disease and pulmonary
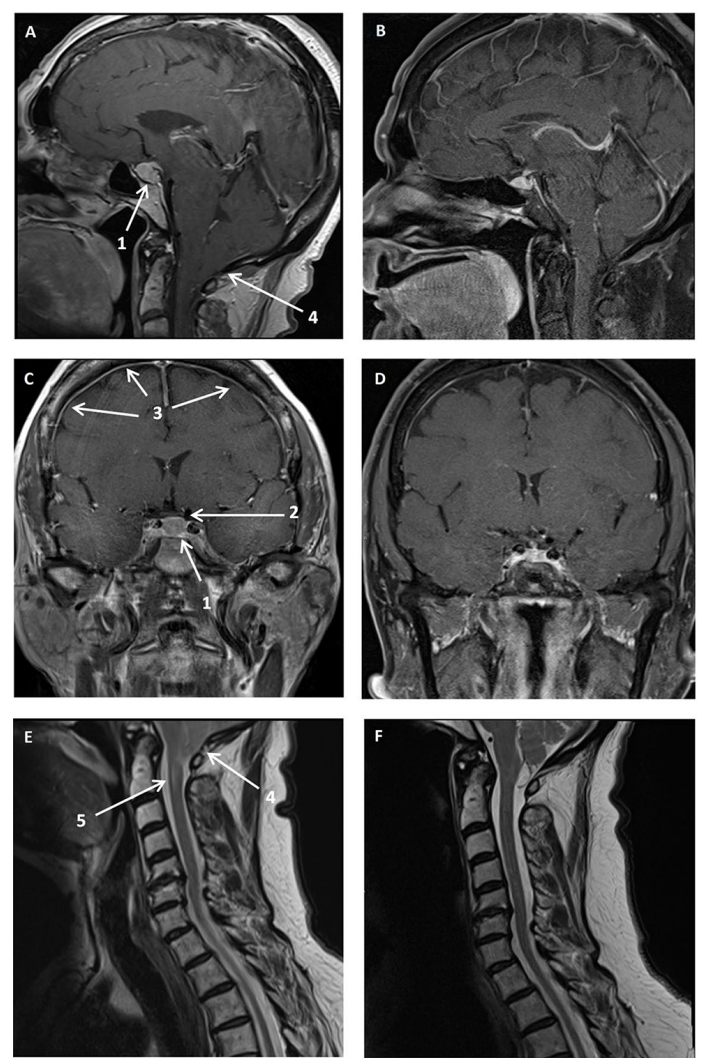

Figure 1 MRI finding reveal signs consistent with intracranial hypotension. Sagittal and coronal images T1 postgadolinium images of the pituitary gland (A-D) and sagittal T2 images through the cervical cord $(\mathrm{E}-\mathrm{F})$. Images in the left column (A, C and $\mathrm{E})$ are taken during lumboperitoneal (LP) shunt overdrainage. They demonstrate pituitary enlargement of $13 \times 9 \times 12 \mathrm{~mm}$ (1), which abuts the optic chiasm (2), mild diffuse pachymeningeal enhancement (3), sagging of the midbrain, tonsillar herniation (4) and a small cervical syrinx at C2 (5). The images in the right column (B, D and F) are taken 6 months after revision of the LP shunt and demonstrate resolution of these abnormal features with pituitary gland dimensions of $6 \times 9 \times 10 \mathrm{~mm}$. disease secondary to cigarette smoking. Physical examination demonstrated normal cranial nerves, bilateral upper motor neuron signs in both upper and lower limbs and severe gait instability.

Her anterior pituitary function testing showed mildly elevated prolactin levels $(69.4 \mu \mathrm{g} / \mathrm{L}$, range $\quad 5.2-26.7 \mu \mathrm{g} / \mathrm{L})$. Adrenocorticotropic hormone (ACTH) deficiency could not be completely excluded on basal testing (ACTH $1.6 \mathrm{pmol} / \mathrm{L}$, range $0.0-10.0 \mathrm{pmol} / \mathrm{L}$; cortisol $245 \mathrm{nmol} / \mathrm{L}$ ). Other pituitary axes were unremarkable. Formal perimetry confirmed normal visual fields. On MRI examination, the pituitary gland was homogenously enlarged $(13 \times 9 \times 12 \mathrm{~mm})$ with a convex superior margin abutting the optic chiasm. There was diffuse pachymeningeal enhancement, tonsillar herniation and a syrinx at $\mathrm{C} 2$ level.

A diagnosis of intracranial hypotension $(\mathrm{IH})$ was made based on clinical presentation and radiological appearance (figure 1). The LP shunt was revised and her signs and symptoms gradually resolved. MRI examination performed 6 months postoperatively confirmed normalisation of her pituitary anatomy $(6 \times 9 \times 10 \mathrm{~mm})$ and resolution of the abnormal features. Basal hormonal levels were retested (ACTH $2.2 \mathrm{pmol} / \mathrm{L}$; cortisol $420 \mathrm{nmol} / \mathrm{L}$ ) and her hyperprolactinaemia had resolved $(21.9 \mu \mathrm{g} / \mathrm{L})$. This patient had acquired IH due to overdrainage of her LP shunt. $\mathrm{IH}$ can be misdiagnosed as pituitary hyperplasia or adenoma.

\section{Learning points}

- Spontaneous or acquired intracranial hypotension $(\mathrm{IH})$ can lead to pituitary enlargement, presumably due to engorgement of pituitary vasculatures to compensate for low intracranial pressure from cerebrospinal fluid loss. ${ }^{1}$

- Hormonal dysfunction, notably hyperprolactinaemia, has been reported and may be caused by an effect of $\mathrm{IH}$ on the pituitary stalk. $^{2}$

- The cardinal signs on MRI are diffuse pachymeningeal enhancement, subdural fluid collections, engorgement of venous sinuses, pituitary enlargement and herniation of the cerebellar tonsils. ${ }^{13}$

Contributors The case was a patient of KW at a public hospital clinic. AYW interpreted the clinical images. DWCC prepared the draft of this clinical picture. KW reviewed and revised the manuscript. All authors approved the final submitted version. The authors acknowledge that they participated sufficiently in the work to take public responsibility for its content. 


\section{Images in...}

\section{Competing interests None declared.}

\section{Patient consent Obtained.}

Provenance and peer review Not commissioned; externally peer reviewed.

(C) BMJ Publishing Group Ltd (unless otherwise stated in the text of the article) 2017. All rights reserved. No commercial use is permitted unless otherwise expressly granted.

\section{REFERENCES}

1 Alvarez-Linera J, Escribano J, Benito-León J, et al. Pituitary enlargement in patients with intracranial hypotension syndrome. Neurology 2000;55:1895-7.

2 Schievink WI, Nuño M, Rozen TD, et al. Hyperprolactinemia due to spontaneous intracranial hypotension. J Neurosurg 2015;122:1020-5.

3 Schievink WI. Spontaneous spinal cerebrospinal fluid leaks and intracranial hypotension. JAMA 2006;295:2286-96.

Copyright 2017 BMJ Publishing Group. All rights reserved. For permission to reuse any of this content visit http://group.bmj.com/group/rights-licensing/permissions.

BMJ Case Report Fellows may re-use this article for personal use and teaching without any further permission.

Become a Fellow of BMJ Case Reports today and you can:

- Submit as many cases as you like

- Enjoy fast sympathetic peer review and rapid publication of accepted articles

Access all the published articles

Re-use any of the published material for personal use and teaching without further permission

For information on Institutional Fellowships contact consortiasales@bmjgroup.com

Visit casereports.bmj.com for more articles like this and to become a Fellow 